\title{
Relationship Between Parenting Pattern with Development Autism Children
}

\author{
Eva Nur Azizah, Sukma Amperiana \\ Pamenang Midwifery Academy, Kediri, Indonesia \\ evanaufal2013@gmail.com
}

\begin{abstract}
The family role to child development is very necessary. Parentshave an autistic child will experience more complex problemsforming personality, behavior and their fulfillmentis needing. The approach was cross sectional. The samples were 30 parents and 30 autistic. The instrument wasused a parenting questionnaire and observation for development. The analysis used contingency coefficient correlation, p-value was 0.017 , smaller than $\alpha=0.05$ $(\mathrm{p}<0.05)$. There was a relationship the association parenting family with development autistic. Parents provide parenting appropriatetheir children without curbing and still paying attention to the child's freedom will be good for the child. Parenting provided to children must be in accordance with the development to needtheir children. The right parenting can provide opportunities for children that they are part of the people in their environment so that children can develop optimally.
\end{abstract}

Keywords: Parenting, Development, Autistic 


\section{STRADA Jurnal Ilmiah Kesehatan}

DOI: $10.30994 /$ sjik.v8i2.224

ISSN: 2252-3847 (print); 2614-350X (online)

Vol.8 No.2. November 2019. Page.146-151

\section{BACKGROUND}

Parenting is a pattern of interaction between parents and children that is how the attitude / behavior of parents when interacting with children, including how to apply the rules, teach values / norms, provide attention and affection and show good attitudes and behavior so that they serve as role models for their children ( Taufik, 2007).

Development is increased skills in structures and functions of the body more complex in a orderly and predictable pattern, body tissues, organs and differentiation organ systems of body cells, body tissues, Organs and organ systems that develop in such a way that each can fulfill its function (Dwi Sulistyo, 2011).

Autism is a very complex developmental disorder in children (Christoper, 2019). Visible symptoms are disruptions in the field of development: the development of two-way interactions, the development of reciprocal interactions, and the development of Behavior (Hasdianah 2013).

Developmental delays in children can be caused by lack of parental knowledge of children's needs. Because in children an autistic developmental delay can become more severe if therapy is not done. The treatment of autistic children is given according to each individual needs (Hargio, 2012). Based on the background above the researchers interested in conducting research on " Theassociation parenting family with development autistic".

\section{OBJECTIVE}

This study aimed to determine relationship the association parenting family with development autistic.

\section{METHODS}

The approach was cross sectional. The research place took from April 2019 until June 2019. Research was conducted in the village of the Sumberbendo Therapeutic center of Pare District, the sampling techniques used was the total sampling. The instruments used in this study are questionnaires and observation sheets. Prior to the study, respondents were given an acceptance of consent for approval of respondents. Then share the questionnaire and provide explanations/instructions on how to fill the questionnaire and give the respondent. Then next day, observe to autistic child. After completion the questionnaire and development observation, researchers gathered the questionnaire. Data analysis was used correlation coefficient of contingency.

\section{RESULTS}

The samples number was 60, with 30 parents and 30 autistic. That got 16 respondents (53.3\%) Autistic child was the mother, her father was $33.3 \%$, the rest was miscellaneous that 16 respondents $(53.3 \%)$. more than Aged was35old, more aged 20-35 years and as much were $46.7 \%$. A total 16 respondents $(53.3 \%)$ were their last education Academy/ bachelor. $43.3 \%$ was, senior high school and 3.3\% was yunior high scholl. A total of 14 respondents $(46.7 \%)$ were Work in private.

Respondents' occupations were $46.7 \%$ as private, $23.3 \%$ as entrepreneurs, $16.7 \%$ as housewife, $13.3 \%$ 


\section{STRADA Jurnal Ilmiah Kesehatan}

DOI: $10.30994 /$ sjik.v8i2.224

ISSN: 2252-3847 (print); 2614-350X (online)

Vol.8 No.2. November 2019. Page.146-151

Table 1. Parenting Parents in Adib Center Therapy

\begin{tabular}{lll}
\hline Parenting & $\mathrm{n}$ & $\%$ \\
\hline Democratic & 11 & $36,7 \%$ \\
Permissive & 10 & $33,3 \%$ \\
Authoritarian & 9 & $30 \%$ \\
Total & 30 & $100 \%$ \\
\hline
\end{tabular}

Based on table 1 it was known that parenting familyto autistic was largely expressed the foster pattern given to his child was a democratic foster pattern of 11 respondents $(36.7 \%)$

Table 2. Development of Autistic Children at Adib Therapy Center

\begin{tabular}{lll}
\hline Parenting & $\mathrm{n}$ & $\%$ \\
\hline Good & 15 & $50 \%$ \\
Less & 15 & $50 \%$ \\
Total & 30 & $100 \%$ \\
\hline
\end{tabular}

\begin{tabular}{llllllllll}
\hline Family Parenting & \multicolumn{3}{l}{ Development } & \multicolumn{4}{c}{ Sum } \\
\cline { 2 - 7 } & \multicolumn{1}{l}{ Less } & \multicolumn{3}{l}{ Good } & \multicolumn{3}{c}{ More } & \\
\cline { 2 - 7 } & $\Sigma$ & $\%$ & $\Sigma$ & $\%$ & $\Sigma$ & $\%$ & $\Sigma$ & $\%$ \\
\hline Democratic & 8 & 26,7 & 2 & 6,7 & 0 & 0 & 10 & 33,3 \\
Permissive & 2 & 6,7 & 9 & 30 & 0 & 0 & 11 & 36,7 \\
Authoritarian & 5 & 16,7 & 4 & 13,3 & 0 & 0 & 9 & 30, \\
Total & 15 & 50 & 15 & 50 & 0 & 0 & 30 & 100 \\
\hline
\end{tabular}

Table 3. Cross Tabulation of the Relationship of Family Parenting with the Development of Autistic Children at Adib Therapy Center

From the results of the calculation was used computer software the contingency coefficient obtained $p$ value $=0.017$ thus the $<\alpha$, the hypothesis of the work $(\mathrm{H} 1)$ was accepted and the zero hypothesis $(\mathrm{H} 0)$ wasrejected meaning there was a link between the With the development of autistic children

\section{DISCUSSION}

Based on the results study was $36.7 \%$ that the parents implemented Democraticparenting,permissive parentingwas $33.3 \%$ and otherAuthoritarian parenting. That data supports parents parentingtype was parents with education (53.3\%) His last education academy/ bachelor $43.3 \%$ Senior high schoolwas $43.3 \%$ and Junior high school was $3.3 \%$. Prasetya (2004) stated that parents who have good education are likely to set a more democratic or permissive foster pattern compared to parents whose education is limited. Meanwhile, according to Supartini (2004) says that a certain age range is good to exercise a parenting role. If it is too young or too old, it may not be able to perform the role optimally because of physical and psychosocial strength.

Some factors that affect the parenting pattern of parents according to (Silalahi\&Meinarno, 2010) of the characteristics of children, age, temperament, gender. From the family characteristics of the number of siblings, social environment, the ability to do and stress, 


\section{STRADA Jurnal Ilmiah Kesehatan}

DOI: $10.30994 /$ sjik.v8i2.224

ISSN: 2252-3847 (print); 2614-350X (online)

Vol.8 No.2. November 2019. Page.146-151

economic and social status, social support.From the characteristics of parents, personality, beliefs and the history of parental development. According to Santrock, the factors affecting foster patterns other than those already expressed by Silalahi are the level of education.

Jarymkeet al. stated that parents of children with autism spectrum disorders face many challenges, especially in parenting. Jarymke compared parenting parenting behavior in children and adolescents with autism spectrum disorders about how parents behave and how children behave.

The behavior of autistic children who are not directed such as crying, laughing, angry without cause, jumping around without a clear purpose, and can not be quiet to make parents stressed. Stress experienced by parents can affect the ability of parents in carrying out the role of caregiving, especially in relation to coping strategies possessed in dealing with children's behavior. And also from the coping strategy factor that is optimism which means parents who have pessimistic thoughts based on individuals when facing problems that appear as a threat compared to parents who have optimistic thoughts can deal with a problem more effectively. So that parents interact less with children (Ma, rifah, 2018)

Child development will be more optimized if the environment in which the child is developing supports them to develop in various aspects. Family environment as the first environment that gives influence to various aspects of child development should be able to create an environment that is conducive to the socialization of children, because the educational process aimed at developing the child's personality is more determined by the family (Pierre\& Forman, 2012)

From the results of the study showed not all the development of autistic children is appropriate, but there is also a lack of development. This is possible because of internal factors, namely racial or ethnic differences, family, sex, genetic, chromosomal abnormalities, prenatal factors, labor and post-natal factors. Not only that it is also possible because of the nutrition obtained by children, because nutritious food plays an important role in children's growth and development.

The majority of autistic child development is influenced by parenting and parental education. Therefore, parents should provide parenting in accordance with the needs of their children so that children are more comfortable and can improve their development properly. Provision of stimulation in children is also able to improve child development. If the child's development is as recommended by parents, as often as possible provide needs and stimulation in accordance with the needs of children. The more mothers meet the appropriate needs, the child can feel more comfortable and can improve their development.

Based on the results of research in addition to work and the number of children that influence the development of autistic children parenting factors also have a major influence on children's development. Parents who provide parenting in accordance with the needs of their children without curbing and still paying attention to the child's freedom will be good for the child. Children are able to adjust to their environment, have courage, so that the child's development is able to develop properly.

Parenting provided to children must be in accordance with the development needs of their children. The right parenting can provide opportunities for children that they are part of the people in their environment so that children can develop optimally. Attention, guidance and knowledge of parents about child development should also be given because it is able to influence the level of children's socialization abilities. 


\section{STRADA Jurnal Ilmiah Kesehatan}

DOI: $10.30994 /$ sjik.v8i2.224

ISSN: 2252-3847 (print); 2614-350X (online)

Vol.8 No.2. November 2019. Page.146-151

\section{CONCLUSION}

There is the associationfamily parenting with development autistic. suggested family parentingto children should do affectionately and without compulsion so to get create a pleasant environment for the child. And the family should spend time and take the best time possible for their children to supervise, to give attention and affection, and communicate so that the family is able to understand to need their children.

\section{ACKNOWLEDGE}

The authors wish to thanks Direktorat Riset dan Pengabdian Masyarakat (DRPM) Kemenristekdikti 2019 wirh research contract 147/SP2H/lt/mono/17/2019. The authors also wish to thanks Terapi Adib Centre.

\section{REFERENCES}

Adriana, D. (2011). Tumbuh Kembang dan Terapi Bermain Pada Anak. Jakarta : Salemba Medika

Cahyaningsih, Dwi Sulistyo. (2011). Pertumbuhan Perkembangan Anak dan Remaja. Jakarta: TIM

Cumo, Christoper. (2019). What You Need Know About Autism. Santa Barbara California : ABC-CLIO,L

Danuatmaja.2008. Rencana Perawatan Maternal. Ed. 2. Jakarta : EGC

Hasdianah. (2013). Autis pada anak.Yogyakarta: Nuha Medika.

Huzaemah. (2010). Kenali Autisme Sejak Dini. Jakarta:PustakaPopuler Obor.

Ma'rifah, Asirotul, dkk. Strategi Koping Orang Tua Terhadap Anak Autis dan Pola Asuh Orang Tua. Jurnal Ilmiah Kesehatan. Vol 11, No 2, 196-204. http://journal2.unusa.ac.id/index.php/JHS/article/view/113/87. Diakses tanggal 4 September 2019

Pierre \& Forman. 2012. Attention-Seeking During Caregiver Unavailability and Collaboration At Age 2. Children Development. Vol 83 No 2 (Maret-April 2012): h.712-727.

Priyatna, Adi.(2010). Amazing Autism. Indonesia : Elex Media Computindo.

Rokhimah, Rina \&Darmawanti Ira. (2013). Pengaruh PermaiananLasy Terhadap Peningkatan Kosentrasi Pada Anak Autis. Jurnal Psikologi Teori \& Terapan, Vol. 4, No.11, 48-55.

Safaria, T. (2005).Interpersonal Intellegence: Metode Pengembangan Kecerdasan Interpersonal Anak.Yogyakarta: Amara Books

Santoso Hargio. (2012). Cara Memahami dan Mendidik Anak Berkebutuhan Khusus. Yogyakarta: Gosyen Publishing

Saputro, H., \& Talan, Y. O. (2017). Pengaruh Lingkungan Keluarga Terhadap Perkembangan Psikososial Pada Anak Prasekolah. Journal Of Nursing Practice, 1(1), 1-8. https://doi.org/10.30994/jnp.v1i1.16

Setyaningsih, Wiwik (2015). Hubungan Pola Asuh Orang Tua Dengan Perkembangan Sosial Anak Autisme di SLB Harmoni Surakarta. Jurnal Kesehatan, Vol 6, No.2, 123 129. http://ejurnal.poltekkes-tjk.ac.id/index.php/JK/article/view/92/83. diakses pada tanggal 4 September 2019

Silalahi, K., \& Meinarno, E. A. (2010). Keluarga Indonesia aspek dan dinamika zaman. Jakarta: Rajawali Pers 


\section{STRADA Jurnal Ilmiah Kesehatan}

DOI: $10.30994 /$ sjik.v8i2.224

ISSN: 2252-3847 (print); 2614-350X (online)

Vol.8 No.2. November 2019. Page.146-151

Taufik, R. (2007). Pola Asuh Orang Tua. www. tabloid_nakita.com (Di download tanggal 8 Januari 2018)

Veskarisyanti, G. A. (2008).12 Terapi Autis Paling Efektif \& Hemat: Untuk Autisme, Hiperaktif \& Retardasi Mental.Yogyakarta: Pustaka Anggrek.

Yatim, F. 2007. Autisme: Suatu Gangguan Jiwa pada Anak-anak. Jakarta: Pustaka Populer Obor 